\title{
Introducing interventional radiology through a longitudinal clinical clerkship
}

This article was published in the following Dove Press journal:

Advances in Medical Education and Practice

\section{Sagar Kulkarni \\ Zia Farooq}

Barts and The London School of Medicine and Dentistry, Queen Mary University of London, London, UK
Correspondence: Sagar Kulkarni Barts and The London School of Medicine and Dentistry, Queen Mary University of London, Garrod Building, Turner Street, London EI 2AD, UK

Email s.kulkarni@smdI3.qmul.ac.uk

\section{Dear editor}

We read with great interest the article by Ojha et $\mathrm{al}^{1}$ in which the authors expressed concern over the lack of doctors choosing interventional radiology (IR) as a subspecialty and predicted a shortage of interventional radiologists in the future. The authors suggest that this shortage may be due to low exposure to IR in the medical curriculum and suggest possible solutions to this issue.

As medical students, we agree that exposure to IR is limited compared to other specialties. The reasons for this are complex; however, we believe that a significant reason is the current structure of the medical curriculum. Traditionally, clinical medicine is taught in a block rotation system, ${ }^{2}$ where medical students rotate through different specialties that are based on the organ systems of the human body, such as cardiology or gastroenterology. With this system, it is difficult to place IR into the curriculum since IR is not defined by a particular organ system; rather, it is defined by the use of minimally invasive, image-guided procedural techniques in many different organ systems. The diversity of modern IR practice acts as a hindrance to its implementation into the medical curriculum.

To combat this difficulty, we suggest that IR should be introduced to medical students via a longitudinal clinical clerkship, where students attend IR sessions related to the specialty that they are currently studying. For instance, students would observe uterine fibroid embolization during their gynecology placement and percutaneous nephrostomy during their urology placement. This approach would allow students to appreciate the role of IR in patient management, which will aid them irrespective of their future career path.

Longitudinal clerkship models have been utilized in medicine previously, such as the Harvard Medical School-Cambridge Integrated Clerkship. ${ }^{2}$ The program offers an integrated approach to learning where students follow patients through their unique health care journey, appreciating the contribution of many different specialists to patient care. ${ }^{2,3}$ The Harvard Medical School-Cambridge Integrated Clerkship program has been used to teach students about the impact of cancer on patients' lives, providing students with insight that would be otherwise unattainable in the traditional block rotation model. ${ }^{4}$

In summary, we agree with Ojha et $\mathrm{al}^{1}$ that the current role of IR in medicine warrants greater exposure to the field among medical students. With regard to implementing curricular change, we suggest a longitudinal clerkship model to enhance student understanding of IR. 


\section{Disclosure}

The authors report no conflicts of interest in this communication.

\section{References}

1. Ojha U, Mohammed R, Vivekanantham S. Should there be greater exposure to interventional radiology in the undergraduate curriculum? Adv Med Educ Pract. 2017;8:791-795.
2. Gaufberg E, Shtasel D, Hirsh D, Ogur B, Bor D. The Harvard Medical School Cambridge Integrated Clerkship: challenges of longitudinal integrated training. Clin Teach. 2008;5(2):78-82.

3. Ogur B, Hirsh D, Krupat E, Bor D. The Harvard Medical School-Cambridge Integrated Clerkship: an innovative model of clinical education. Acad Med. 2007;82(4):397-404.

4. Ghosh A, Hirsh DA, Ogur B, Schwaitzberg SD. Teaching medical students about cancer impact through a longitudinal surgical experience: a case study. Teach Learn Med. 2012;24(2):158-162.

Dove Medical Press encourages responsible, free and frank academic debate. The content of the Advances in Medical Education and Practice 'letters to the editor' section does not necessarily represent the views of Dove Medical Press, its officers, agents, employees, related entities or the Advances in Medical Education and Practice editors. While all reasonable steps have been taken to confirm the content of each letter, Dove Medical Press accepts no liability in respect of the content of any letter, nor is it responsible for the content and accuracy of any letter to the editor.

Advances in Medical Education and Practice

Dovepress

\section{Publish your work in this journal}

Advances in Medical Education and Practice is an international, peerreviewed, open access journal that aims to present and publish research on Medical Education covering medical, dental, nursing and allied health care professional education. The journal covers undergraduate education, postgraduate training and continuing medical education including emerging trends and innovative models linking education, research, and health care services. The manuscript management system is completely online and includes a very quick and fair peer-review system. Visit http://www.dovepress.com/testimonials.php to read real quotes from published authors.

Submit your manuscript here: http://www.dovepress.com/advances-in-medical-education-and-practice-journal 